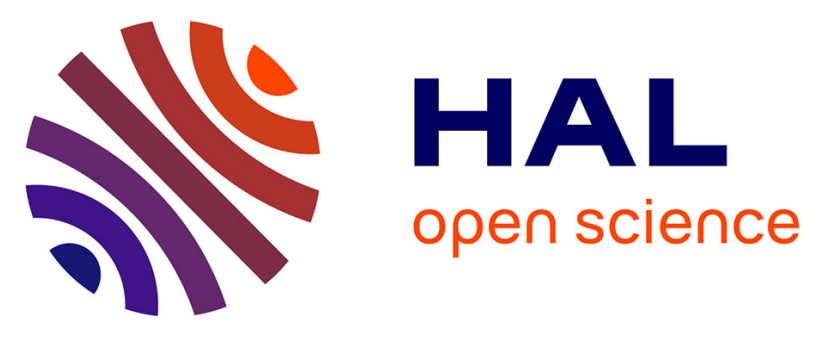

\title{
Influence of the HCV subtype on the virological response to pegylated interferon and ribavirin therapy.
}

Florence Legrand-Abravanel, Philippe Colson, Helene Le Guillou-Guillemette, Laurent Alric, Isabelle Ravaux, Françoise Lunel-Fabiani, Magali Bouvier-Alias, Pascale Trimoulet, Marie-Laure Chaix, Christophe Hezode, et al.

\section{To cite this version:}

Florence Legrand-Abravanel, Philippe Colson, Helene Le Guillou-Guillemette, Laurent Alric, Isabelle Ravaux, et al.. Influence of the HCV subtype on the virological response to pegylated interferon and ribavirin therapy.. Journal of Medical Virology, 2009, 81 (12), pp.2029. 10.1002/jmv.21583 . hal-00531821

\section{HAL Id: hal-00531821 \\ https://hal.science/hal-00531821}

Submitted on 4 Nov 2010

HAL is a multi-disciplinary open access archive for the deposit and dissemination of scientific research documents, whether they are published or not. The documents may come from teaching and research institutions in France or abroad, or from public or private research centers.
L'archive ouverte pluridisciplinaire HAL, est destinée au dépôt et à la diffusion de documents scientifiques de niveau recherche, publiés ou non, émanant des établissements d'enseignement et de recherche français ou étrangers, des laboratoires publics ou privés. 


\section{INFLUENCE OF THE HCV SUBTYPE ON THE VIROLOGICAL RESPONSE TO PEGYLATED INTERFERON AND RIBAVIRIN THERAPY}

\begin{tabular}{|c|c|}
\hline Journal: & Journal of Medical Virology \\
\hline Manuscript ID: & JMV-09-1244.R1 \\
\hline Wiley - Manuscript type: & Research Article \\
\hline $\begin{array}{r}\text { Date Submitted by the } \\
\text { Author: }\end{array}$ & 20-May-2009 \\
\hline Complete List of Authors: & $\begin{array}{l}\text { Abravanel, Florence; Toulouse University hospital, Virology; Inserm } \\
\text { U563 } \\
\text { Colson, Philippe; Marseille university hospital, virology } \\
\text { Le Guillou-Guillemette, Helene; Angers university hospital, virology } \\
\text { Alric, Laurent; Toulouse University Hospital, Medecine Interne } \\
\text { Ravaux, Isabelle; infectious diseases; Marseille university hospital, } \\
\text { virology } \\
\text { Lunel-Fabiani, F; chu angers, maine et loire } \\
\text { Bouvier-Alias, Magali; CHU Mondor, virology } \\
\text { Trimoulet, Pascale; CHU de Bordeaux, Virologie; Université Victor } \\
\text { Ségalen, Virologie EA2968 } \\
\text { Chaix, Marie-Laure; CHU Necker, virology } \\
\text { Fontaine, Helene; CHU Cochin, Gastroenterology } \\
\text { Hezode, Christophe; CHU Mondor, gastroenterology } \\
\text { Foucher, Juliette; CHU Bordeaux, Gastroenterology } \\
\text { Roque-Afonso, Anne-Marie; CHU Paul Brousse, virology } \\
\text { Gassin, Michele; CHU Nantes, Virology } \\
\text { Schvoerer, Evelyne; CHU Stasbourg, virology } \\
\text { Gaudy, Catherine; CHU Tours, virology } \\
\text { Roche, Bruno; CHU Paul Brousse, Gastroenterology } \\
\text { Doffoel, Michel; CHU Strasbourg, Gastroenterology } \\
\text { Dalteroche, Louis; CHU Tours, gastroenterology } \\
\text { Vallet, Sophie; CHU Brest, virology } \\
\text { Baazia, Yazid; CHU Avicenne, virology } \\
\text { Pozzetto, Bruno; CHu Saint Etienne, Virology } \\
\text { Thibault, Vincent; CHU Pitié salpétrière, virology } \\
\text { Nousbaum, Jean-baptiste; CHU Brest, Gastroenterology } \\
\text { Roulot, Dominique; Hôpital Jean Verdier, gastroenterology } \\
\text { Coppere, Henry; CHU Saint Etienne, gastroenterology } \\
\text { Poynard, Thierry; CHU pitie salpetriere, gastroenterology } \\
\text { Payan, Christopher; CHU Brest, virology } \\
\text { Izopet, Jacques; Institut Fédératif de Biologie de Purpan, } \\
\text { Laboratoire de Virologie }\end{array}$ \\
\hline
\end{tabular}


Keywords: HCV subtype, interferon, ribavirin

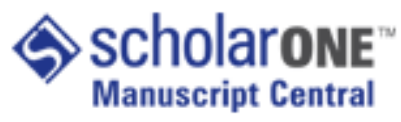




\section{INFLUENCE OF THE HCV SUBTYPE ON THE VIROLOGICAL RESPONSE TO PEGYLATED INTERFERON AND RIBAVIRIN THERAPY}

5 Florence Legrand-Abravanel ${ }^{1}$, Philippe Colson $^{2}$, Hélène Leguillou-Guillemette ${ }^{3}$, Laurent Alric ${ }^{4}$, Isabelle Ravaux ${ }^{5}$, Françoise Lunel-Fabiani ${ }^{3}$, Magali Bouviers-Alias ${ }^{7}$, Pascale Trimoulet $^{8}$, Marie Laure Chaix ${ }^{9}$, Christophe Hézode ${ }^{10}$, Juliette Foucher ${ }^{11}$, Hélène Fontaine ${ }^{12}$, Anne-Marie Roque-Afonso ${ }^{13}$, Michèle Gassin ${ }^{14}$, Evelyne Schvoerer ${ }^{15}$, Catherine Gaudy ${ }^{16}$, Bruno Roche ${ }^{17}$, Michel Doffoël ${ }^{18}$, Louis

D'Alteroche $^{19}$, Sophie Vallet ${ }^{20}$, Yazid Baazia ${ }^{21}$, Bruno Pozzetto ${ }^{22}$, Vincent Thibault ${ }^{23}$, Jean-Baptiste Nousbaum ${ }^{24}$, Dominique Roulot ${ }^{25}$, Henry Coppere ${ }^{26}$, Thierry Poinard $^{27}$, Christopher Payan ${ }^{20}$ and Jacques Izopet ${ }^{1}$

${ }^{1}$ Laboratoire de virologie, Centre Hospitalier-Universitaire, Toulouse ; ${ }^{2}$ Laboratoire 15 de virologie, Centre Hospitalier-Universitaire, Marseille ; ${ }^{3}$ Laboratoire de virologie, Centre Hospitalier-Universitaire, Angers ; ${ }^{4}$ Médecine interne, Centre HospitalierUniversitaire, Toulouse ; ${ }^{5}$ Service de maladie infectieuse Centre HospitalierUniversitaire, Marseille; ${ }^{6}$ Service de Gastroentérologie, Centre HospitalierUniversitaire, Angers; 7 Laboratoire de virologie, Centre Hospitalier-Universitaire 20 Mondor, Créteil ; 8 Laboratoire de virologie, Centre Hospitalier-Universitaire, Bordeaux ; ${ }^{9}$ Laboratoire de virologie, Centre Hospitalier-Universitaire Necker, Paris ; ${ }^{10}$ Service de Gastroentérologie, Centre Hospitalier-Universitaire Mondor, Creteil ; ${ }^{11}$ Service de Gastroentérologie, Centre Hospitalier-Universitaire Bordeaux, ${ }^{12}$ Service d'hépatologie Hôpital Cochin, Paris ; ${ }^{13}$ Laboratoire de virologie, Centre Hospitalier25 Universitaire Paul Brousse, Paris ; ${ }^{14}$ Laboratoire de virologie, Centre Hospitalier- 
Universitaire, Nantes; ${ }^{15}$ Laboratoire de virologie, Centre Hospitalier-Universitaire, Strasbourg ; ${ }^{16}$ Laboratoire de virologie, Centre Hospitalier-Universitaire, Tours ; ${ }^{17}$ Centre hépatobiliaire Centre Hospitalier-Universitaire, Paul-Brousse, Paris ${ }^{18}$ Service de Gastroentérologie Centre Hospitalier-Universitaire, Strasbourg, ${ }^{19}$ Service de

5 Gastroentérologie Centre Hospitalier-Universitaire, Tours, ${ }^{20}$ Laboratoire de virologie, Centre Hospitalier-Universitaire, Brest ; ${ }^{21}$ Laboratoire de virologie, Centre Hospitalier-Universitaire Avicenne, Bobigny; ${ }^{22}$ Laboratoire de virologie, Centre Hospitalier-Universitaire, Saint-Etienne ; ${ }^{23}$ Laboratoire de virologie, Centre Hospitalier-Universitaire Pitié-Salpétrière, Paris ; ${ }^{24}$ Service de Gastroentérologie, 10 Centre Hospitalier-Universitaire, Brest, ${ }^{25}$ Service de Gastroentérologie, Centre Hospitalier Jean Verdier, Bondy, ${ }^{26}$ Service de Gastroentérologie Centre HospitalierUniversitaire Saint-Etienne, ${ }^{27}$ Service de Gastroentérologie Centre HospitalierUniversitaire Pitié-Salpétrière, Paris. 


\section{ABSTRACT}

The hepatitis $\mathrm{C}$ virus genotype is considered to be the most important baseline predictor of a sustained virological response in patients with chronic hepatitis C

5 treated with pegylated interferon and ribavirin. The influence of the subtype on the sustained virological response was investigated in patients infected with genotypes 1 , 4, 5 or 6 . This study was done on 597 patients with chronic hepatitis $C$ who were given pegylated interferon and ribavirin for 48 weeks. The overall rate of sustained virological response in the 597 patients was $37.8 \%$. Univariate analysis indicated that

10 the sustained virological response of patients infected with subtype $1 \mathrm{~b}(39 \%)$ tended to be higher than that of patients infected with subtype $1 a(30.6 \% ; p=0.06)$ and it was similar to those patients infected with subtypes $4 a(51.3 \%, p=0.12)$ or $4 d(51.7 \%$, $\mathrm{p}=0.16)$. Multivariate analysis indicated that five factors were independently associated with sustained virological response: the age $(\mathrm{OR} 0.97 ; 95 \% \mathrm{Cl}=0.95$ -

15 0.99), absence of cirrhosis (OR: 2.92;95\% Cl =1.7-5.0; $\mathrm{p}<0.01$ ), absence of HIV coinfection (OR: 2.08; $95 \% \mathrm{Cl}=1.2-3.5 ; \mathrm{p}<0.01$ ), low baseline plasma HCV RNA concentration (OR: $1.74 ; 95 \% \mathrm{Cl}=1.2-2.6 ; \mathrm{p}<0.01)$ and the subtype $1 \mathrm{~b}(\mathrm{OR}: 1.61$; $95 \% \mathrm{Cl}=1.0-2.5 ; \mathrm{p}=0.04)$ or subtypes $4 \mathrm{a}$ and $4 \mathrm{~d}(\mathrm{OR}: 2.03 ; 95 \% \mathrm{Cl}=1.1-3.8$; $\mathrm{p}=0.03)$. In conclusion, among difficult-to-treat genotypes, the subtype $1 \mathrm{a}$ is 20 associated with a lower response to anti-HCV therapy than subtypes 1b, 4a and 4d. 


\section{INTRODUCTION}

Hepatitis $\mathrm{C}$ virus (HCV) infection is a major health care burden worldwide. $\mathrm{HCV}$ is a single-stranded, positive-polarity RNA virus belonging to the genus 5 Hepacivirus of the family Flaviviridae. The HCV genome has the following gene order: 5'-C-E1-E2-p7-NS2-NS3-NS4A-NS4B-NS5A-NS5B-3' and encodes a single long polyprotein [Lindenbach and Rice, 2005]. The sequences of the genomes of HCV variants differ considerably and have been divided into six genotypes. Each of these 6 genotypes can be further subdivided into a series of subtypes [Simmonds et 10 al., 2005].

Anti-HCV therapy has progressed significantly in recent years. The standard and most effective initial treatment for chronic hepatitis $\mathrm{C}$ is a combination of pegylated interferon-alpha plus ribavirin [Fried et al., 2002; Manns et al., 2001]. The HCV genotype is considered to be the most important baseline predictor of a

15 sustained virological response in patients with chronic hepatitis C. Treatment is effective in approximately $80 \%$ of patients infected with HCV genotype 2 or 3 but is less than $50 \%$ in those infected with HCV genotype 1 [Fried et al., 2002; Hadziyannis et al., 2004; Manns et al., 2001]. Genotype 4 is considered as a difficult-to-treat genotype [Legrand-Abravanel et al., 2005; Martin-Carbonero et al., 2008; Roulot et 20 al., 2007; Zeuzem, 2004], even if high sustained virological response rates (67-70\%) have been reported for patients in the Middle East infected with genotype 4 [Hasan et al., 2004; Kamal et al., 2005]. The sensitivity of genotypes 5 and 6 to interferon and ribavirin may be similar to that of genotypes 2 and 3 [Bonny et al., 2006; Fung et al., 2008; Hui et al., 2003; Legrand-Abravanel et al., 2004]. However, treatment for 48 25 weeks is still recommended for patients infected with genotypes 5 or 6 . 
Most commercial assays determine the genotype by analysing the 5'UTR. But the 5'UTR is highly conserved, which limits its use for discriminating genotype 6 from genotype 1 and subtypes within genotypes 1, 2, 3, 4, and 6 [Cantaloube et al., 2006; Chen and Weck, 2002; Sandres-Saune et al., 2003]. For example, the G residue at 5 position 243 of the 5'UTR was originally considered to be representative of subtype $1 \mathrm{~b}$, but it also occurs in a substantial proportion of subtype 1a viruses. Many studies have shown that the NS5B region is discriminative for determining HCV genotypes and their subtypes [Cantaloube et al., 2006; Sandres-Saune et al., 2003]. However, most clinical trials have determined the genotype by analysing the 5'UTR region, 10 making it impossible to study the influence of the subtype on the virological response, especially in difficult-to-treat patients infected with HCV genotypes 1 or 4 .

An observational study was therefore carried out on a large group of patients to evaluate the influence of HCV subtype on the response to pegylated interferon plus ribavirin. 


\section{PATIENTS AND METHODS}

\section{Patient selection}

A total of 14 centers in France took part in the study between January 2004 and June 2007. Patients were selected in the present study based on the following criteria: (i)

5 patients were infected with HCV-1, 4, 5 and 6 only; (ii) subjects could be naïve or not for previous interferon-based therapy; (iii) patients could be or not coinfected with human immunodeficiency virus (HIV) or the hepatitis B virus (HBV). The following data were collected: age, gender, geographical origin of the patients, source of transmission, and co-infection with HIV or HBV, and Metavir score of liver biopsies.

\section{Patient description}

Five hundred and ninety seven patients were included, $67.7 \%$ were men (Table 1 ). The mean age was $48.9 \pm 11.1$ years old. One hundred and ninety three $(32.3 \%)$ had been previously treated with a standard interferon-based regimen. Fourteen patients

15 were infected with HBV and 141 were also infected with HIV. Approximately one quarter of the patients (23.4\%) who underwent a liver biopsy had cirrhosis.

\section{Treatment}

20 Patients were given pegylated interferon alpha-2a (Pegasys, Roche laboratories, Palo Alto, CA), 180 g/week, or pegylated interferon alpha-2b (PEG-Intron, Schering Plough, Kenilworth, $\mathrm{NJ}), 1.5 \mu \mathrm{g} / \mathrm{kg} /$ week, at the discretion of the physician, combined with ribavirin (Copegus, Roche laboratories or Rebetol, Schering Plough), 1000 $\mathrm{mg} /$ day if the body weight was $\leq 75 \mathrm{~kg}$, or $1200 \mathrm{mg} /$ day if the body weight was $>75$

$25 \mathrm{~kg}$, for 48 weeks. The doses of pegylated interferon and ribavirin were modified according to standard criteria and procedures [Dienstag and McHutchison, 2006]. 
Patients with an undetectable HCV RNA or with a $>2$ log decline in HCV-RNA at week 12 were considered to be early virological responders and were treated for 48 weeks. The treatment of patients with a $<2$ log decline at week 12 was stopped and they were considered to be non-responders. All patients were followed up for 24 5 weeks after the end of treatment. The primary end point was undetectable serum HCV-RNA 24 weeks after treatment cessation.

\section{HCV RNA quantitation}

HCV-RNA was measured at baseline and 12 weeks after beginning the treatment 10 with Versant HCV-RNA 3.0 bDNA (Siemens Healthcare Diagnostics, Tarrytown, NY) (limit of detection: $615 \mathrm{IU} / \mathrm{ml}$ ), or Cobas Taqman Roche Diagnostics (Roche Molecular Systems, Pleasanton, CA) (limit of detection: $15 \mathrm{IU} / \mathrm{ml}$ ), depending on the assay used routinely in each center. The plasma HCV RNA concentrations measured with the bDNA test were adjusted to take into account the mean difference between

15 the two assays [Pittaluga et al., 2008]. Values of $0.49 \log$ copies/ml for genotype 1a, $0.45 \log$ copies $/ \mathrm{ml}$ for genotype $1 \mathrm{~b}$, and $0.26 \mathrm{log}$ copies $/ \mathrm{ml}$ for genotype 4 were added to plasma HCV RNA concentrations measured with the bDNA test $(n=269)$. The plasma HCV RNA concentrations of patient infected with genotype 5 were not adjusted since the mean difference between the two assays is less than 0.05 log 20 copies /ml [Sarrazin et al., 2006; Vermehren et al., 2008]. Similarly, the plasma RNA HCV concentration measured in patients infected with genotype 6 was not adjusted as no data are available on the quantitation for this genotype with the two assays.

\section{HCV genotyping}


The HCV genotype was determined by sequencing a $382 \mathrm{nt}$ fragment within the NS5B region of the HCV genome [Laperche et al., 2005; Sandres-Saune et al., 2003].

\section{Statistical analysis}

Statistical analysis was performed with the software Stata 8.0 (Stata Corporation, Grand Forks, ND). Non-parametric tests were used to compare the differences between the groups (Mann-Whitney $U$ test for continuous variable; $X^{2}$ test for parametric variables). A p value of less than 0.05 was considered to be significant.

10 Baseline predictors of the virological response were evaluated by univariate and multivariate analyses. The following covariates were analysed: type of pegylated interferon (pegylated interferon alpha-2a or pegylated interferon alpha-2b), previous interferon-based therapy, sex, age as continuous variable, geographical origin of the patients, liver cirrhosis (F4 score according to the METAVIR classification), HBV and HIV co-infection, baseline plasma HCV RNA concentration, classified as $\leq 800000$ $\mathrm{IU} / \mathrm{ml}(5.9 \mathrm{log} \mathrm{IU} / \mathrm{ml})$ or $>800000 \mathrm{IU} / \mathrm{ml}$, HCV genotype and HCV subtypes 1a, 1b, $4 a$ and $4 d$. Variables with a $p$ value of 0.10 or less after univariate analysis were entered into a multivariate, backward, stepwise logistic regression analysis to identify significant variables associated independently with the virological response. Odds

20 ratios were estimated from the model and are given with their $95 \%$ confidence intervals. Patients infected with non genotypes $1 \mathrm{a}, 1 \mathrm{~b}, 4 \mathrm{a}$ and $4 \mathrm{~d}$ were excluded from the analyses due to the low number of patients within each subtype. Since they presented the same early and sustained virological response, patients infected with subtypes $4 \mathrm{a}$ and $4 \mathrm{~d}$ were grouped to increase the number of subjects. 
The statistical analysis was confirmed independently by Dr M Delobel-Ayoub (Inserm Unit 558). 


\section{RESULTS}

\section{Genotype distribution}

The demographic and clinical characteristics of the 597 patients are

5 summarized in Table 1. The HCV genotypes were $1(n=494), 4(n=91), 5(n=8)$, and $6(n=4)$. The distribution of the subtypes is outlined in Table 2. Of the patients infected with genotype $1,44.5 \%(n=220)$ were infected with the subtype 1 a and $51.2 \%(n=253)$ with subtype $1 b$. The patients infected with genotype 4 showed a wider range of subtypes, with more than 9 subtypes identified, although subtypes $4 a$ $10(40.7 \%)$ and $4 d(31.8 \%)$ were the main ones.

\section{Early virological response}

Almost two-thirds of the patients (64.1\%) had a virological response, defined as an undetectable HCV RNA or a 2-log decline from baseline HCV RNA, by week

15 12. The early virological responses for each subtype are shown in Table 2. Univariate analysis identified 6 factors that were associated with an early virological response: the type of pegylated interferon, previous interferon-based treatment, absence of cirrhosis, co-infection with HIV, low baseline HCV RNA and the genotype. Patients given pegylated interferon alpha 2 a had a better early virological response $(67.8 \%)$

20 than patients given pegylated interferon alpha $2 b(54.3 \%, p<0.01)$. The early virological response of interferon-experienced patients was poorer (56\%) than that of naive patients $(69 \%, p<0.01)$. Similarly, the early virological response rate of cirrhotic patients was lower $(48.4 \%)$ than that of non-cirrhotic patients $(67.7 \%, p<0.01)$. Patients infected with both HIV and HCV had a lower early virological response rate $25(48.2 \%)$ than patients infected with $\mathrm{HCV}$ alone $(69 \%, \mathrm{p}<0.01)$. Patients with a low 
baseline HCV RNA ( $\leq 800000 \mathrm{IU} / \mathrm{ml}$, or $5.9 \mathrm{log} \mathrm{IU} / \mathrm{ml}$ ) have a better early virological response $(73.6 \%)$ than patients with a high baseline HCV RNA (> $800000 \mathrm{IU} / \mathrm{ml}$, or $5.9 \log \mathrm{IU} / \mathrm{ml}$ ) (58.4\%). Patients infected with genotype 1 or 4 had similar early virological responses (61.4 and $64.1 \%, \mathrm{p}=0.56)$. Whereas, all the patients infected

5 with genotypes 5 or 6 had undetectable HCV RNA by week 12. Patients infected with genotype $1 \mathrm{a}$ or $1 \mathrm{~b}$ had similar early virological responses $(61.4 \%$ and $64.4 \%$, $p=0.52)$, as did patients infected with genotype $4 a$ or $4 d(64.8 \%$ and $66.6 \%, p=0.84)$. No difference according to gender, geographical origin of the patients or HBV coinfection was observed. Multivariate analysis indicated that five factors were 10 independently associated with the early virological response: treatment with pegylated interferon alpha-2a, interferon-naive patients, absence of cirrhosis, absence of co-infection with HIV and low plasma HCV RNA concentration at baseline $(\leq 5.9 \log \mathrm{UI} / \mathrm{mL})($ Table 3$)$

15 Sustained virological response

The overall rate of sustained virological response was $37.8 \%$ for the 597 patients. The rates of sustained virological response according to the subtype are shown in Table 2. Univariate analysis identified seven factors that were associated with a sustained virological response: previous interferon-based treatment, age, 20 cirrhosis, co-infection with HIV, viral load before treatment, HCV genotype and HCV subtype. Patients who had previously failed to respond interferon-based therapy were less likely to have a sustained virological response $(29 \%)$ than were naive patients $(43 \%, \mathrm{p}<0.01)$. The responders were younger (47.3 years) than the nonresponders $(49.8$ years, $p<0.01)$. The rate of sustained virological response of 25 patients without cirrhosis was $42.2 \%$; it was only $19.1 \%$ in patients with a cirrhosis 
$(p<0.01)$. The rate of sustained virological response for HIV-HCV co-infected patients was lower $(28.3 \%)$ than that of patients infected with HCV alone $(40.7 \% ; p<0.01)$. Patients with a low baseline HCV RNA ( $\leq 800000 \mathrm{IU} / \mathrm{ml}$ ) have a better sustained virological response (48.6\%) than patients with an higher baseline HCV RNA (32.1\%;

$5 \mathrm{p}<0.01)$. The sustained virological response of patients infected with genotype 4 was significantly higher $(49.4 \%)$ than that of patients infected with genotype $1(35.4 \%)$ $(p=0.01)$. Genotype 5 infected patients had a low sustained virological response rate $(37.5 \%)$ similar to that of patients infected with genotype 1 . Those patients infected with subtype 1a tended to have a lower sustained virological response rate $(30.6 \%)$ 10 than those infected with subtype $1 \mathrm{~b}(39 \% ; p=0.06)$, and it was lower than patients infected with genotype $4 a(51.3 \%, p<0.01)$ or $4 d(51.7 \%, p<0.01)$. Patients infected with genotype $1 \mathrm{~b}, 4 \mathrm{a}$, and $4 \mathrm{~d}$ presented the same rate of sustained virological response $(p>0.10)$. Neither gender, geographical origin, nor HBV co-infection influenced the rate of sustained virological response. Multivariate analysis revealed 15 five factors that were independently associated with a sustained virological response: the age, absence of cirrhosis, absence of HIV coinfection, low baseline plasma HCV RNA concentration ( $\leq 5.9 \log \mathrm{UI} / \mathrm{mL}$ ) and the subtypes $1 \mathrm{~b}$, $4 \mathrm{a}$ or $4 \mathrm{~d}$ (Table 3 ). 


\section{DISCUSSION}

A large observational study of chronic hepatitis C-infected patients was conducted to assess the influence of virus subtype on the virological response to

5 pegylated interferon and ribavirin therapy. The subtype was accurately determined by phylogenetic analyses of the NS5B region of the HCV genome. Multivariate analysis revealed that the subtypes $1 \mathrm{~b}, 4 \mathrm{a}$, and $4 \mathrm{~d}$ were independent variable associated with the sustained virological response.

Several factors influence the rate of sustained virological response to 10 pegylated interferon and ribavirin therapy: pharmacological, host and virological factors [Everson et al., 2006; Fried et al., 2002; Manns et al., 2001; Nicot et al., 2008; Zeuzem, 2004]. In the present study, patients treated with pegylated interferon alpha2a had a better early virological response than patient treated with pegylated interferon alpha $2 \mathrm{~b}$. However, the type of pegylated interferon did not influence the

15 sustained virological response. This is in keeping with the results of the IDEAL trial where patients treated with pegylated interferon alpha $2 \mathrm{a}$ and ribavirin had a better end-of-treatment response than patients treated with pegylated interferon alpha $2 \mathrm{~b}$, but the sustained virological responses of the two groups were similar [Sulkowski et al., 2008]. HIV-HCV patients show the same difference in the early virological 20 responses of the patients treated with pegylated interferon alpha-2a and patients treated with pegylated interferon alpha-2b [Vispo et al., 2008].

Patients who had failed a previous interferon-based therapy had a lower sustained virological response. Several trials on HCV-infected and HIV-HCV coinfected patients have shown that retreatment of (pegylated) interferon25 experienced patients with pegylated interferon and ribavirin combination therapy 
results in a much lower sustained virological response rate than treatment of (pegylated) interferon-naive patients [Camma et al., 2002; Krawitt et al., 2005; Sherman et al., 2006].

In the present work, older age and cirrhosis and HIV coinfection were

5 associated with a poor sustained virological response. It is well established that these host factors are independent predictors of nonresponse to interferon-based treatment of patients with chronic hepatitis C [Everson et al., 2006; Fried et al., 2002; MartinCarbonero et al., 2008; Zeuzem, 2004].

Baseline plasma HCV RNA concentration is a viral factor influencing the 10 treatment in chronic hepatitis C in most studies [Fried et al., 2002; Manns et al., 2001; McHutchison et al., 1998; Poynard et al., 1998]. Baseline plasma HCV RNA concentration and virological response at week 4 may now influence the treatment duration in genotype 1 infected patients [Ferenci et al., 2008; Yu et al., 2008; Zeuzem et al., 2006]. In the present work, the statistical analyses found a higher early and 15 sustained virological response rate in patients with low baseline plasma HCV RNA concentration. The same result was obtained when the analyses were conducted without adjusting the HCV RNA concentrations for genotype 1 and 4 .

The HCV genotype is considered to be the most important baseline predictor of a sustained virological response in patients with chronic hepatitis C. A low 20 sustained virological response rate was found for patients infected with genotype 5 (37.5\%), unlike previous findings for this genotype [Bonny et al., 2006; LegrandAbravanel et al., 2004]. The findings of these two studies were supported by comparison with two control groups of patients infected with genotypes 1 or $2 / 3$. The discrepancy with previous work may be because genotype 5-infected patients in the 25 present work were more likely to suffer from cirrhosis and were older than the other 
patients in the present study. Only 4 patients were infected with genotype 6 , but the rates of early or sustained virological response in this group of patients were very good, as previously described [Fung et al., 2008; Hui et al., 2003].

Several clinical trials have found that patients infected with genotypes 1 or 4

5 are less likely to achieve a sustained virological response [Fried et al., 2002; Legrand-Abravanel et al., 2005; Manns et al., 2001; Martin-Carbonero et al., 2008; Roulot et al., 2007]. A previous retrospective study found that French patients infected with subtype $4 \mathrm{a}$ had a higher rate of sustained virological response $(58 \%)$ than those infected with subtype $4 d(43 \%, p=0.035)$ [Roulot et al., 2007]. A study has 10 reported a group of ten HIV-positive patients who were acutely infected with HCV genotype $4 \mathrm{~d}$. None of the 10 patients treated early with antiviral therapy had a sustained virological response, suggesting that this subtype is less sensitive to interferon-based therapy [Serpaggi et al., 2006]. However, no difference in the virological responses of patients infected with subtypes $4 \mathrm{a}$ or $4 \mathrm{~d}$ was found at week

1512 or 6 months after completion of the therapy. By contrast, among difficult-to-treat genotypes, patients infected with subtype $1 \mathrm{~b}, 4 \mathrm{a}$ and $4 \mathrm{~d}$ had a higher sustained virological response than those infected with subtype 1a. This was not reported before because most studies, including pivotal studies on pegylated interferon-alpha $2 \mathrm{a}$ and pegylated interferon-alpha $2 \mathrm{~b}$ registration, determined the HCV genotype 20 using a method based on the 5'UTR region that does not discriminate accurately the subtypes [Fried et al., 2002; Manns et al., 2001]. Therefore, the influence of the subtype could not be determined.

In conclusion, in patients infected with difficult-to-treat genotypes, the subtype 1a may be considered as a pejorative factor of response to antiviral therapy. Further 
studies are needed to identify the molecular basis of this difference and to assess the possibility of using the genotype 1 subtype to optimize anti-HCV therapy.

\section{AKNOWLEGMENTS}

5

We are grateful to Dr. Malika Delobel-Ayoub, Inserm Unit 558, for performing an independent statistical analysis. This work was supported by the Agence Nationale de Recherche contre le SIDA et les Hepatites Virales (ANRS), AC11 HCV Study Group. 


\section{REFERENCES}

Bonny C, Fontaine H, Poynard T, Hezode C, Larrey D, Marcellin P, Bourliere M, Bronowicki JP, Merle P, Zarski JP, Sapey T, Guillemard C, Ughetto S, Henquell C, Nicolas C, Roche C, Randl K, Bommelaer G, Abergel A. 2006. Effectiveness of interferon plus ribavirin combination in the treatment of naive patients with hepatitis $C$ virus type 5 . A French multicentre retrospective study. Alimentary pharmacology \& therapeutics 24(4):593-600.

Camma C, Bruno S, Schepis F, Lo lacono O, Andreone P, Gramenzi AG, Mangia A, Andriulli A, Puoti M, Spadaro A, Freni M, Di Marco V, Cino L, Saracco G, Chiesa A, Crosignani A, Caporaso N, Morisco F, Rumi MG, Craxi A. 2002. Retreatment with interferon plus ribavirin of chronic hepatitis $C$ nonresponders to interferon monotherapy: a meta-analysis of individual patient data. Gut 51(6):864-869.

15 Cantaloube JF, Laperche S, Gallian P, Bouchardeau F, de Lamballerie X, de Micco P. 2006. Analysis of the 5 ' noncoding region versus the NS5b region in genotyping hepatitis $C$ virus isolates from blood donors in France. Journal of clinical microbiology 44(6):2051-2056.

Chen Z, Weck KE. 2002. Hepatitis C virus genotyping: interrogation of the $5^{\prime}$ untranslated region cannot accurately distinguish genotypes $1 \mathrm{a}$ and $1 \mathrm{~b}$. Journal of clinical microbiology 40(9):3127-3134.

Dienstag JL, McHutchison J. 2006. American Gastroenterological Association Technical Review on the Management of Hepatitis C. Gastroenterology 130:231-264.

25 Everson GT, Hoefs JC, Seeff LB, Bonkovsky HL, Naishadham D, Shiffman ML, Kahn JA, Lok AS, Di Bisceglie AM, Lee WM, Dienstag JL, Ghany MG, Morishima C. 2006. Impact of disease severity on outcome of antiviral therapy for chronic hepatitis C: Lessons from the HALT-C trial. Hepatology (Baltimore, Md 44(6):1675-1684.

30 Ferenci P, Laferl H, Scherzer TM, Gschwantler M, Maieron A, Brunner H, Stauber R, Bischof M, Bauer B, Datz C, Loschenberger K, Formann E, Staufer K, SteindlMunda P. 2008. Peginterferon alfa-2a and ribavirin for 24 weeks in hepatitis $C$ type 1 and 4 patients with rapid virological response. Gastroenterology 135(2):451-458.

35 Fried MW, Shiffman ML, Reddy KR, Smith C, Marinos G, Goncales FL, Jr., Haussinger D, Diago M, Carosi G, Dhumeaux D, Craxi A, Lin A, Hoffman J, Yu J. 2002. Peginterferon alfa-2a plus ribavirin for chronic hepatitis $C$ virus infection. The New England journal of medicine 347(13):975-982.

Fung J, Lai CL, Hung I, Young J, Cheng C, Wong D, Yuen MF. 2008. Chronic hepatitis $C$ virus genotype 6 infection: response to pegylated interferon and ribavirin. The Journal of infectious diseases 198(6):808-812.

Hadziyannis SJ, Sette H, Jr., Morgan TR, Balan V, Diago M, Marcellin P, Ramadori G, Bodenheimer H, Jr., Bernstein D, Rizzetto M, Zeuzem S, Pockros PJ, Lin A, Ackrill AM. 2004. Peginterferon-alpha2a and ribavirin combination therapy in chronic hepatitis $\mathrm{C}$ : a randomized study of treatment duration and ribavirin dose. Annals of internal medicine 140(5):346-355. 
Hui CK, Yuen MF, Sablon E, Chan AO, Wong BC, Lai CL. 2003. Interferon and ribavirin therapy for chronic hepatitis $C$ virus genotype 6: a comparison with genotype 1. The Journal of infectious diseases 187(7):1071-1074.

Krawitt EL, Ashikaga T, Gordon SR, Ferrentino N, Ray MA, Lidofsky SD. 2005. Peginterferon alfa-2b and ribavirin for treatment-refractory chronic hepatitis $\mathrm{C}$. Journal of hepatology 43(2):243-249.

Legrand-Abravanel F, Nicot F, Boulestin A, Sandres-Saune K, Vinel JP, Alric L, Izopet J. 2005. Pegylated interferon and ribavirin therapy for chronic hepatitis $C$ virus genotype 4 infection. Journal of medical virology 77(1):66-69.

10 Legrand-Abravanel F, Sandres-Saune K, Barange K, Alric L, Moreau J, Desmorat P, Vinel JP, Izopet J. 2004. Hepatitis C virus genotype 5: epidemiological characteristics and sensitivity to combination therapy with interferon-alpha plus ribavirin. The Journal of infectious diseases 189(8):1397-1400.

Lindenbach BD, Rice CM. 2005. Unravelling hepatitis C virus replication from genome to function. Nature 436(7053):933-938.

Manns MP, McHutchison JG, Gordon SC, Rustgi VK, Shiffman M, Reindollar R, Goodman ZD, Koury K, Ling M, Albrecht JK. 2001. Peginterferon alfa-2b plus ribavirin compared with interferon alfa-2b plus ribavirin for initial treatment of chronic hepatitis C: a randomised trial. Lancet 358(9286):958-965.

20 Martin-Carbonero L, Puoti M, Garcia-Samaniego J, De Luca A, Losada E, Quinzan G, Bruno R, Marino A, Gonzalez M, Nunez M, Soriano V. 2008. Response to pegylated interferon plus ribavirin in HIV-infected patients with chronic hepatitis $C$ due to genotype 4 . Journal of viral hepatitis.

McHutchison JG, Gordon SC, Schiff ER, Shiffman ML, Lee WM, Rustgi VK, Goodman ZD, Ling MH, Cort S, Albrecht JK. 1998. Interferon alfa-2b alone or in combination with ribavirin as initial treatment for chronic hepatitis $\mathrm{C}$. Hepatitis Interventional Therapy Group. The New England journal of medicine 339(21):1485-1492.

Nicot F, Legrand-Abravanel F, Lafont T, Dubois M, Saune K, Pasquier C, Chatelut E, Izopet J. 2008. Serum concentrations of ribavirin and pegylated interferon and viral responses in patients infected with HIV and HCV. Journal of medical virology 80(9):1523-1529.

Pittaluga F, Allice T, Abate ML, Ciancio A, Cerutti F, Varetto S, Colucci G, Smedile A, Ghisetti V. 2008. Clinical evaluation of the COBAS Ampliprep/COBAS TaqMan for HCV RNA quantitation in comparison with the branched-DNA assay. Journal of medical virology 80(2):254-260.

Poynard T, Marcellin P, Lee SS, Niederau C, Minuk GS, Ideo G, Bain V, Heathcote J, Zeuzem S, Trepo C, Albrecht J. 1998. Randomised trial of interferon alpha2b plus ribavirin for 48 weeks or for 24 weeks versus interferon alpha2b plus placebo for 48 weeks for treatment of chronic infection with hepatitis $C$ virus. International Hepatitis Interventional Therapy Group (IHIT). Lancet 352(9138):1426-1432.

Roulot D, Bourcier V, Grando V, Deny P, Baazia Y, Fontaine H, Bailly F, Castera L, De Ledinghen V, Marcellin P, Poupon R, Bourliere M, Zarski JP, RoudotThoraval F. 2007. Epidemiological characteristics and response to peginterferon plus ribavirin treatment of hepatitis $C$ virus genotype 4 infection. Journal of viral hepatitis 14(7):460-467.

Sandres-Saune K, Deny P, Pasquier C, Thibaut V, Duverlie G, Izopet J. 2003. Determining hepatitis $C$ genotype by analyzing the sequence of the NS5b region. Journal of virological methods 109(2):187-193. 
Sarrazin C, Gartner BC, Sizmann D, Babiel R, Mihm U, Hofmann WP, von Wagner M, Zeuzem S. 2006. Comparison of conventional PCR with real-time PCR and branched DNA-based assays for hepatitis $C$ virus RNA quantification and clinical significance for genotypes 1 to 5 . Journal of clinical microbiology 44(3):729-737.

Sherman M, Yoshida EM, Deschenes M, Krajden M, Bain VG, Peltekian K, Anderson F, Kaita K, Simonyi S, Balshaw R, Lee SS. 2006. Peginterferon alfa-2a (40KD) plus ribavirin in chronic hepatitis $C$ patients who failed previous interferon therapy. Gut 55(11):1631-1638.

10 Simmonds P, Bukh J, Combet C, Deleage G, Enomoto N, Feinstone S, Halfon P, Inchauspe G, Kuiken C, Maertens G, Mizokami M, Murphy DG, Okamoto H, Pawlotsky JM, Penin F, Sablon E, Shin IT, Stuyver LJ, Thiel HJ, Viazov S, Weiner AJ, Widell A. 2005. Consensus proposals for a unified system of nomenclature of hepatitis $\mathrm{C}$ virus genotypes. Hepatology (Baltimore, Md 42(4):962-973.

Sulkowski M, Lawitz E, Shiffman ML, Muir AJ, Galler G, McCone J, Nyberg L, M. Lee W, Ghalib R, Schiff E, Galati J, Bacon B, Davis M, Mukhopadhyay P, Noviello S, Pedicone L, Albrecht J, McHutchison J. 2008. Final results of the IDEAL (Individualised dosing efficacy versus flat dosing to assess optimal pegylated interferon therapy) phase IIIB study Journal of hepatology 48 (S2):S370-S371

Vermehren J, Kau A, Gartner BC, Gobel R, Zeuzem S, Sarrazin C. 2008. Differences between two real-time PCR based assays (RealTime HCV, COBAS AmpliPrep/COBAS TaqMan) and one signal amplification assay (VERSANT HCV RNA 3.0) for HCV RNA detection and quantification. Journal of clinical microbiology.

Vispo E, Barreiro P, Rodriguez-Novoa S, Morello J, Labarga P, Martin-Carbonero L, Maida I, Garcia-Gasco P, Soriano V. 2008. Distinct hepatitis C virus kinetics in HIV-infected patients treated with ribavirin plus either pegylated interferon alpha2a or alpha2b. Antiviral therapy 13(4):511-517.

30 Yu ML, Dai CY, Huang JF, Chiu CF, Yang YH, Hou NJ, Lee LP, Hsieh MY, Lin ZY, Chen SC, Hsieh MY, Wang LY, Chang WY, Chuang WL. 2008. Rapid virological response and treatment duration for chronic hepatitis $\mathrm{C}$ genotype 1 patients: a randomized trial. Hepatology (Baltimore, Md 47(6):1884-1893.

Zeuzem S. 2004. Heterogeneous virologic response rates to interferon-based therapy in patients with chronic hepatitis C: who responds less well? Annals of internal medicine 140(5):370-381.

Zeuzem S, Buti M, Ferenci P, Sperl J, Horsmans Y, Cianciara J, Ibranyi E, Weiland O, Noviello S, Brass C, Albrecht J. 2006. Efficacy of 24 weeks treatment with peginterferon alfa-2b plus ribavirin in patients with chronic hepatitis $C$ infected with genotype 1 and low pretreatment viremia. Journal of hepatology 44(1):97103. 
Table 1. Baseline characteristics of the 597 treated patients

\begin{tabular}{|c|c|c|c|c|c|}
\hline Characteristic & $\begin{array}{c}\text { Total } \\
(n=597)\end{array}$ & $\begin{array}{c}\text { Genotype } 1 \\
(n=494)\end{array}$ & $\begin{array}{c}\text { Genotype } 4 \\
(n=91)\end{array}$ & $\begin{array}{c}\text { Genotype } 5 \\
(n=8)\end{array}$ & $\begin{array}{c}\text { Genotype } 6 \\
(n=4)\end{array}$ \\
\hline \multicolumn{6}{|l|}{ Gender, n (\%) } \\
\hline Female & $193(33)$ & $159(32.8)$ & $30(33)$ & $4(50)$ & 0 \\
\hline Male & $404(67)$ & $335(67.8)$ & $61(67)$ & $4(50)$ & $4(100)$ \\
\hline Age, mean years \pm SD & $48.9 \pm 11.1$ & $49.3 \pm 11.2$ & $45.2 \pm 8.5$ & $63.2 \pm 8.9$ & $59.8 \pm 7.3$ \\
\hline \multicolumn{6}{|l|}{ Source of infection, $n(\%)$} \\
\hline Blood transfusion & $132(22.1)$ & $120(24.3)$ & $9(9.9)$ & $3(37.5)$ & 0 \\
\hline Drug abuse & $194(32.5)$ & $159(32.1)$ & $35(38.5)$ & 0 & 0 \\
\hline Nosocomial & $40(6.7)$ & $32(6.5)$ & $5(5.5)$ & $2(25)$ & $1(25)$ \\
\hline Sexual & $11(1.8)$ & $8(1.6)$ & $3(3.3)$ & 0 & 0 \\
\hline Unknown & 222 (37.3) & $175(35.5)$ & $39(42.8)$ & $3(37.5)$ & $3(75)$ \\
\hline \multicolumn{6}{|l|}{ Liver Fibrosis, n (\%)* } \\
\hline F0-3 & $412(76.6)$ & $336(75.2)$ & $68(86.1)$ & $5(62.5)$ & $3(75)$ \\
\hline $\mathrm{F} 4$ & $126(23.4)$ & $111(24.8)$ & $11(13.9)$ & $3(37.5)$ & $1(25)$ \\
\hline \multicolumn{6}{|l|}{ Co-infection, n (\%) } \\
\hline HIV & $141(23.6)$ & $112(22.6)$ & $29(31.8)$ & 0 & 0 \\
\hline HBV & $14(2.3)$ & $12(2.4)$ & $2(2.2)$ & 0 & 0 \\
\hline $\begin{array}{l}\text { Mean HCV RNA (log } \\
I \mathrm{IU} / \mathrm{mL})( \pm \mathrm{SD})\end{array}$ & $6.10 \pm 0.6$ & $6.15 \pm 0.6$ & $5.87 \pm 0.6$ & $5.80 \pm 0.5$ & $6.21 \pm 0.8$ \\
\hline $\begin{array}{l}\text { Range HCV RNA (log } \\
\text { IU } / \mathrm{mL})\end{array}$ & $3.34-8.29$ & $3.44-8.29$ & $3.34-7.47$ & $5.34-6.83$ & $5.16-6.89$ \\
\hline \multicolumn{6}{|l|}{$\begin{array}{l}\text { Previous interferon based } \\
\text { therapy }\end{array}$} \\
\hline Yes & $193(32.3)$ & $172(34.8)$ & $20(22)$ & $1(12)$. & 0 \\
\hline No & $404(67.7)$ & $322(65.3)$ & $71(78)$ & 7 (87.5) & $4(100)$ \\
\hline \multicolumn{6}{|l|}{ Treatment } \\
\hline Peg-IFN $\alpha-2 a+$ Ribavirin & $436(73.1 \%)$ & $361(73.1 \%)$ & $65(74.1 \%)$ & $4(75 \%)$ & $4(100 \%)$ \\
\hline Peg-IFN $\alpha-2 b+$ Ribavirin & $161(26.9 \%)$ & $133(26.9 \%)$ & $26(28.6 \%)$ & $2(25 \%)$ & 0 \\
\hline
\end{tabular}

*Data were unavailable for 59 patients, including 47 in the genotype 1 group and 12 in the genotype 4 group. 
Table 2. Virological responses according to the genotype and subtype

\begin{tabular}{|c|c|c|c|c|}
\hline Genotype & Subtype & $n$ & $\begin{array}{l}\text { Early virological } \\
\text { response, } n \text { (\%) }\end{array}$ & $\begin{array}{c}\text { Sustained } \\
\text { virological } \\
\text { response, } n(\%)\end{array}$ \\
\hline \multirow[t]{4}{*}{1} & all subtypes & 494 & $310(62.7)$ & $175(35.4)$ \\
\hline & $1 \mathrm{a}$ & 220 & $135(61.4)$ & $68(30.6)$ \\
\hline & $1 b$ & 253 & $161(64.1)$ & 98 (39) \\
\hline & other subtypes & 21 & $14(66.6)$ & $9(42.8)$ \\
\hline \multirow[t]{4}{*}{4} & all subtypes & 91 & $60(65.9)$ & $48(52.7)$ \\
\hline & $4 a$ & 37 & $24(64.8)$ & $19(51.3)$ \\
\hline & $4 d$ & 29 & $22(66.6)$ & $15(51.7)$ \\
\hline & other subtypes & 25 & $17(68)$ & $12(48)$ \\
\hline 5 & $5 a$ & 8 & $8(100)$ & $3(37.5)$ \\
\hline 6 & all subtypes & 4 & $4(100)$ & $3(75)$ \\
\hline
\end{tabular}


Table 3: Multivariate analysis of factors associated with virological response.

\begin{tabular}{|c|c|c|c|c|}
\hline & $n$ & Odds ratio & $95 \% \mathrm{Cl}$ & $P$ value \\
\hline Early virological response & 538 & & & \\
\hline \multicolumn{5}{|l|}{ Type of pegylated interferon } \\
\hline Peg-IFN $\alpha 2 b$ & 143 & 1 & & \\
\hline \multicolumn{3}{|l|}{ Previous interferon based therapy } & $1.7-3.9$ & $<0.01$ \\
\hline Yes & 184 & 1 & & \\
\hline \multicolumn{5}{|l|}{ Cirrhosis } \\
\hline Yes & 126 & 1 & & \\
\hline \multicolumn{5}{|l|}{ HIV coinfection } \\
\hline Yes & 124 & 1 & & \\
\hline \multicolumn{5}{|l|}{ Baseline HCV RNA } \\
\hline $\begin{array}{l}>5.9 \mathrm{log} \mathrm{IU} / \mathrm{ml} \\
\leq 5.9 \mathrm{log} \mathrm{IU} / \mathrm{ml}\end{array}$ & $\begin{array}{l}190 \\
348\end{array}$ & $\begin{array}{c}1 \\
2.06\end{array}$ & $1.4-3.1$ & $<0.01$ \\
\hline Sustained virological response & 484 & & & \\
\hline \multicolumn{5}{|l|}{$\begin{array}{l}\text { Age } \\
\text { Cirrhosis }\end{array}$} \\
\hline Yes & 117 & 1 & & \\
\hline $\begin{array}{l}\text { No } \\
\text { HIV coinfection }\end{array}$ & 367 & 2.92 & $1.7-5.0$ & $<0.01$ \\
\hline Yes & 129 & 1 & & \\
\hline $\begin{array}{l}\text { No } \\
\text { Baseline HCV RNA }\end{array}$ & \multicolumn{3}{|c|}{ Baseline HCV RNA } & $<0.01$ \\
\hline$>5.9 \mathrm{log} \mathrm{IU} / \mathrm{ml}$ & 323 & 1 & & \\
\hline $\begin{array}{l}\leq 5.9 \mathrm{log} \mathrm{IU} / \mathrm{ml} \\
\text { Subtypes }\end{array}$ & 164 & 1.74 & $1.2-2.6$ & $\begin{array}{l}<0.01 \\
0.03\end{array}$ \\
\hline $1 \mathrm{a}$ & 201 & 1 & & \\
\hline $1 \mathrm{~b}$ & 226 & 1.61 & $1.0-2.5$ & 0.04 \\
\hline $4 a+4 d$ & 57 & 2.03 & $1.1-3.8$ & 0.03 \\
\hline
\end{tabular}

